\title{
Limnological Characteristics Reveal Metal Pollution Legacy in Lakes near Canada's Northernmost Mine, Little Cornwallis Island, Nunavut
}

\author{
Branaavan Sivarajah, ${ }^{1,2}$ Neal Michelutti, ${ }^{1}$ Xiaowa Wang, ${ }^{3}$ Christopher Grooms ${ }^{1}$ and John P. Smol ${ }^{1}$
}

(Received 25 August 2020; accepted in revised form 6 January 2021)

\begin{abstract}
We compared modern limnological characteristics of three lakes near the world's northernmost base metal (lead-zinc) mine, Polaris Mine, which operated from 1981 to 2002 on Little Cornwallis Island (Nunavut, Canada), to a suite of sites from Resolute Bay (Qausuittuq), Cornwallis Island. Although both study regions are underlain by broadly similar geology and experience nearly identical climatic conditions, present-day water chemistry variables differed markedly between sites on the two islands. Specifically, the lakes near the Polaris Mine recorded substantially higher concentrations of zinc and lead, as well as several other heavy metals (cadmium, molybdenum, nickel, uranium, vanadium), relative to the sites on Cornwallis Island. Although the Polaris Mine closed in 2002, elevated levels of heavy metals in our 2017 survey are likely a legacy of contamination from prior operations.
\end{abstract}

Key words: Polaris Mine; lead-zinc mining; water chemistry; base metal mines; legacy contaminants

RÉSUMÉ. Nous avons comparé les caractéristiques limnologiques modernes de trois lacs situés à proximité de la mine de métaux communs (plomb-zinc) la plus au nord du globe, soit la mine Polaris exploitée de 1981 à 2002 sur la Petite île Cornwallis (Nunavut, Canada), à une série de sites de la baie Resolute (Qausuittuq) sur l'île Cornwallis. Même si les deux régions à l'étude possèdent une géologie grandement similaire et qu'elles connaissent des conditions climatiques quasi identiques, les variables de la composition chimique de l'eau actuelle affichaient des différences considérables entre les sites des deux îles. Plus précisément, les lacs à proximité de la mine Polaris avaient des concentrations de plomb et de zinc nettement supérieures ainsi que plusieurs autres métaux lourds (cadmium, molybdène, nickel, uranium, vanadium) comparativement aux sites de l'île Cornwallis. Même si la mine Polaris a fermé ses portes en 2002, la présence de taux élevés de métaux lourds dans notre levé de 2017 découle vraisemblablement de la contamination émanant d'activités antérieures.

Mots clés : Mine Polaris; exploitation du plomb et du zinc; composition chimique de l'eau; mines de métaux communs; contaminants hérités

Traduit pour la revue Arctic par Nicole Giguère.

\section{INTRODUCTION}

Rich in natural resources, Canada's North has a long history of mining activities (Silke, 2009; Keeling and Sandlos, 2015). For example, the discovery of lead-zinc ores on Little Cornwallis Island (Nunavut, High Arctic Canada) in the 1960s led to the establishment of the Polaris Mine $\left(75.39^{\circ} \mathrm{N}, 96.94^{\circ} \mathrm{W}\right.$ ) in the early 1980s (Dewing et al., 2006). This site became the world's northernmost base metal mine, with underground operations lasting for two decades (1981-2002; Donald, 2005; Dewing et al., 2006). The operational history of the Polaris Mine has been presented by Nassichuk (1987) and Dewing et al. (2006). Annually, Polaris Mine produced about 250000 to 300000 tonnes of wet zinc and lead concentrates (Nassichuk, 1987), which were stored on site prior to being shipped to Belgium for smelting (Donald, 2005). However, 15 million tonnes of mine tailings from the concentrator were dewatered and routed to the bottom of nearby Garrow Lake (Donald, 2005; Dewing et al., 2006), a naturally meromictic lake with an anoxic hypolimnion that is separated from the upper mixolimnion because of a strong salinity gradient (Ouellet et al., 1989; Markager et al., 1999). Garrow Lake was strategically selected as a tailings storage site because its meromictic nature would presumably contain the waste metals in the hypolimnion with little danger of mixing into surface waters (Donald, 2005). However, there were at least two instances of a breach in the tailings line (1985 and 1989) that discharged mine wastes into the upper layer of the lake and resulted in elevated zinc concentrations (Gartner Lee Ltd., 2001). The mining operations ended in 2002 and surface remediation activities were subsequently undertaken (Donald, 2005).

\footnotetext{
${ }^{1}$ Paleoecological Environmental Assessment and Research Laboratory, Department of Biology, Queen's University, Kingston, Ontario K7L 3N6, Canada

${ }^{2}$ Corresponding author: branaavan.sivarajah@queensu.ca

${ }^{3}$ Aquatic Contaminants Research Division, Environment and Climate Change Canada, Burlington, Ontario L7S 1A1, Canada

(C) The Arctic Institute of North America
} 
Here, we compare present-day water chemistry variables from the directly impacted Garrow Lake and two other lakes located near the former mine site (Fig. 1) to limnological data from a suite of lakes and ponds near the Polar Continental Shelf Program (PCSP) base at Resolute Bay (Cornwallis Island, Nunavut). Our goal was to assess whether the modern limnology of lakes located near the abandoned Polaris Mine differed from those on nearby Cornwallis Island, which has no history of mining activities. Both study islands have broadly similar surface geology and climatic conditions with very little vegetation cover (Thorsteinsson, 1958; Edlund, 1992). Comparative limnological surveys such as these are useful tools to understand the past impacts of anthropogenic disturbances in Arctic regions, which are under increasing pressure from resource extraction projects, but where long-term monitoring data are sparse (e.g., Houben et al., 2016; Palmer et al., 2019; Sivarajah et al., 2019).

\section{MATERIALS AND METHODS}

Water samples were collected from Garrow Lake (maximum depth $=49 \mathrm{~m}$; surface area $=4.1 \mathrm{~km}^{2}$; Ouellet et al., 1989) and two other nearby sites (unofficial names Little Cornwallis 1 and 2) near the former Polaris Mine site on 31 July 2017 (Fig. 1). Little Cornwallis 1 is a small lake (surface area $=0.03 \mathrm{~km}^{2}$ ), located adjacent to the aircraft landing strip, while Little Cornwallis 2 is a larger lake (surface area $=1.68 \mathrm{~km}^{2}$ ) about $2 \mathrm{~km}$ north of Garrow Lake (Fig. 1). We also collected water samples from 10 lakes $\left(Z_{\max }>2 \mathrm{~m}\right)$ and ponds $\left(\mathrm{Z}_{\max }<2 \mathrm{~m}\right)$ near Resolute Bay (Qausuittuq) on Cornwallis Island during the same sampling season between late July and early August 2017. We followed field-sampling protocols that have been routinely used and described in our previous limnological surveys of lakes and ponds in the Canadian High Arctic to ensure consistency and comparison among all sites (e.g., Lim et al., 2001; Michelutti et al., 2002, 2007; Antoniades et al., 2003; Keatley et al., 2007). The water samples for this investigation were collected from a depth of $\sim 30 \mathrm{~cm}$ near the shoreline and kept cool $\left(\sim 4^{\circ} \mathrm{C}\right)$ in the field and during transportation. Littoral zone sampling is common for High Arctic summer limnological surveys when ice conditions are typically precarious for mid-lake sampling. Specific conductance and $\mathrm{pH}$ were measured using handheld meters at the base camp in Resolute Bay shortly after sample collection. The water samples were then analyzed for a variety of water chemistry variables related to metals, cations, anions, and nutrients at the National Laboratory for Environmental Testing in Burlington (Ontario, Canada) following standard protocols outlined in Environment Canada's Manual of Analytical Methods (EC, 1994a, b) and described in Michelutti et al. (2019).

In this limnological survey, we measured more than 50 water chemistry variables for each of the 13 study sites. Prior to conducting numerical analyses, we removed variables that contained concentrations below detection limits (BDL) in more than half the lakes, following similar procedures used in Antoniades et al. (2003) and Michelutti et al. (2019). This removal resulted in the elimination of chlorophyll-corrected, ammonia, and several elements (beryllium, bismuth, germanium, indium, niobium, platinum, scandium, silver, thallium, tin, and zirconium) from further numerical treatments. Parameters that had concentrations BDL in five lakes or less (BDL at 1 site cadmium, BDL at two sites - tungsten, BDL at three sites gallium and titanium, BDL at four sites - cesium, BDL at five sites - tellurium and zinc) were replaced with the value of the detection limit (Michelutti et al., 2019; Sivarajah et al., 2019). Next, we screened all water chemistry variables for normality using the Shapiro-Wilk test in R statistical software environment (R Core Team, 2019). Particulate organic carbon $(\mathrm{POC})$, particulate organic nitrogen $(\mathrm{PON})$, $\mathrm{pH}$, total dissolved nitrogen (TDN), soluble reactive phosphorus (SRP), dissolved inorganic carbon (DIC), and silica were normally distributed. However, many other variables had skewed distributions in this dataset, and some were log-transformed (fluoride, sulfate, total dissolved phosphorus [TDP], calcium, aluminum, antimony, barium, boron, cadmium, cerium, chromium, cobalt, copper, gallium, iron, lanthanum, lithium, manganese, molybdenum, tungsten, uranium, vanadium, and yttrium), while others were square-root-transformed (total Kjeldahl dissolved nitrogen [TKDN], total phosphorus [TP], arsenic). Certain variables could not be normalized using $\log$ or square-root transformations as exceptionally high concentrations were recorded in lakes around the Polaris Mine site (Table 1).

A preliminary principal component analysis (PCA) was conducted with all the normal and transformed variables $(n=33)$ to explore the distribution of the 13 sites in ordination space using the $\mathrm{R}$ statistical environment. Since strong correlations among multiple variables were apparent in the preliminary PCA (See Supplementary file, Appendix 1: Fig. S1), a Pearson correlation matrix was generated in the R statistical environment to identify positively correlated variables and to remove variables that were redundant (Appendix 1: Table S1). For example, TDN was chosen to represent TKDN (correlation coefficient $(r)=0.97)$ and POC tracked PON $(r=0.89)$ as these variables were strongly correlated with each other. A final PCA of the 13 sites was conducted with the remaining 21 variables.

\section{RESULTS}

The concentrations of several variables related to the ionic strength of the water (e.g., specific conductance, chloride, magnesium, sodium, potassium) and certain metals (e.g., lead, nickel, strontium, zinc) were higher in the lakes near the Polaris Mine (Table 1). In particular, the concentrations of lead and zinc were exceptionally high at Garrow and Little Cornwallis 1 (the lake near the landing 


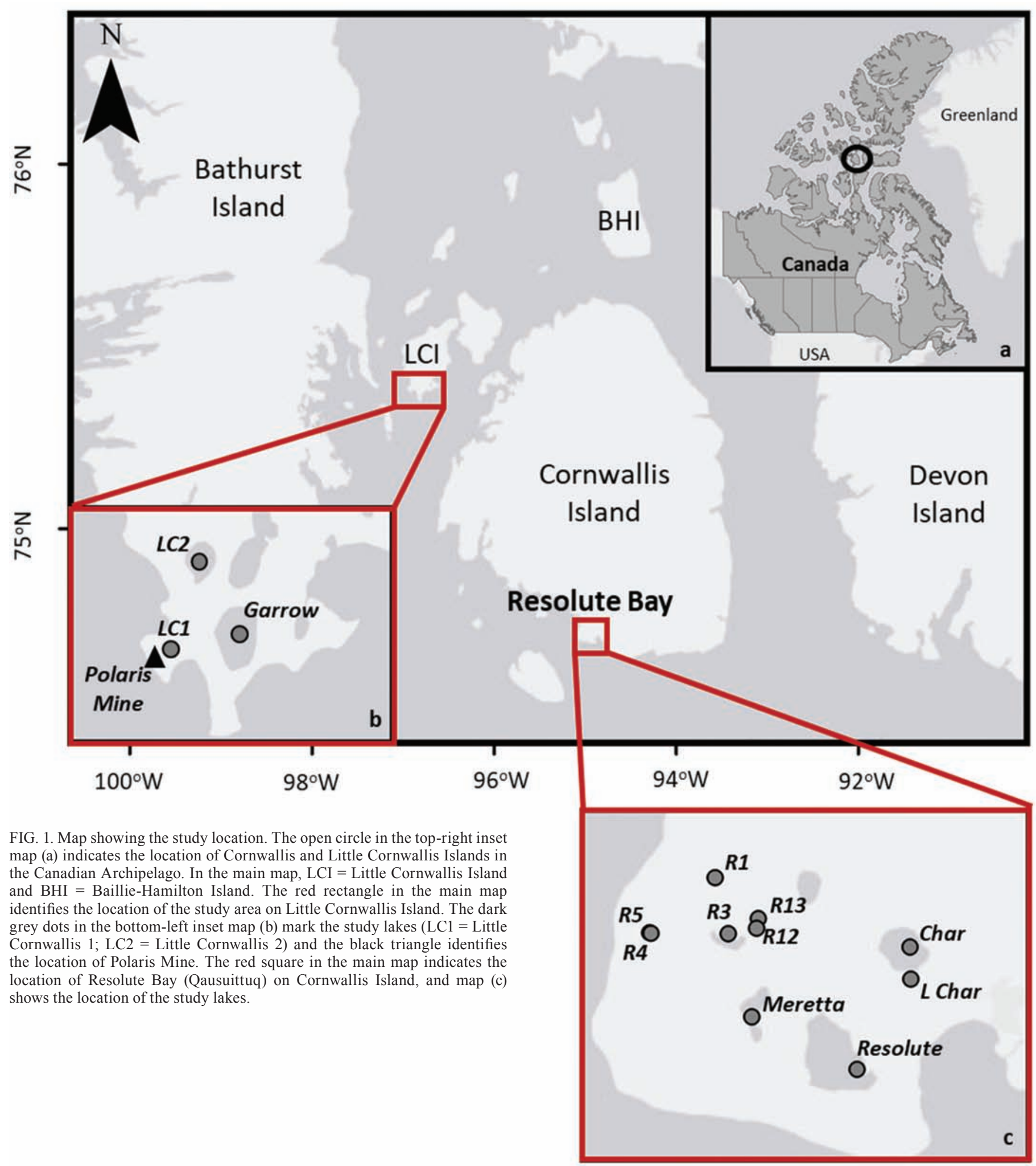

strip) (Fig. 2). Since the variables listed in Table 1 could not be normalized using various transformations, they were not included in the PCA. This was due to the higher levels recorded at Garrow Lake and Little Cornwallis 1 compared to Little Cornwallis 2 and the 10 sites in Resolute Bay (Table 1). The initial PCA of all the normalized variables

allowed us to identify notable differences in the limnology of lakes in Little Cornwallis Island and Resolute Bay, and it was apparent that several variables were highly correlated (Appendix 1: Fig. S1). The Pearson correlation identified several strong positive relationships among water chemistry variables (Appendix 1: Table S1). Since sulfate was 
TABLE 1. The locations (latitude and longitude in decimal degrees) of the three lakes on Little Cornwallis Island along with measurements of water chemistry variables that could not be normalized using log or square-root transformations. The median values from the 10 Resolute Bay sites are provided for comparison.

\begin{tabular}{|c|c|c|c|c|c|c|c|c|}
\hline Lake & Lat. (dd) & Long. (dd) & Conduc. ${ }^{1}(\mu \mathrm{S} / \mathrm{cm})$ & $\mathrm{Cl}^{-}(\mathrm{mg} / \mathrm{L})$ & $\mathrm{NO}_{2}{ }^{-} / \mathrm{NO}_{3}{ }^{-}$as $\mathrm{N}(\mathrm{mg} / \mathrm{L})$ & $\mathrm{Mg}(\mathrm{mg} / \mathrm{L})$ & $\mathrm{Na}(\mathrm{mg} / \mathrm{L})$ & $\mathrm{K}(\mathrm{mg} / \mathrm{L})$ \\
\hline Garrow & 75.3964 & -96.8263 & 3080 & 1000 & 0.106 & 79 & 626 & 18.5 \\
\hline L. Cornwallis 1 & 75.3915 & -96.9223 & 957 & 102 & 0.070 & 29.5 & 76.6 & 5.89 \\
\hline L. Cornwallis 2 & 75.4241 & -96.8484 & 321 & 24 & 0.024 & 9.62 & 13.3 & 1.07 \\
\hline \multirow[t]{2}{*}{ Resolute Bay median } & & & 283 & 15.9 & 0.008 & 8.54 & 11.65 & 0.575 \\
\hline & $\mathrm{Cs}(\mu \mathrm{g} / \mathrm{L})$ & $\mathrm{Pb}(\mu \mathrm{g} / \mathrm{L})$ & $\mathrm{Ni}(\mu \mathrm{g} / \mathrm{L})$ & $\mathrm{Rb}(\mu \mathrm{g} / \mathrm{L})$ & $\operatorname{Se}(\mu \mathrm{g} / \mathrm{L})$ & $\operatorname{Sr}(\mu \mathrm{g} / \mathrm{L})$ & $\operatorname{Ti}(\mu \mathrm{g} / \mathrm{L})$ & $\mathrm{Zn}(\mu \mathrm{g} / \mathrm{L})$ \\
\hline Garrow & 0.022 & 9.78 & 1.84 & 4.78 & 0.38 & 722 & 2.1 & 53.6 \\
\hline L. Cornwallis 1 & 0.003 & 6.06 & 1.55 & 0.709 & 0.32 & 296 & 0.3 & 152 \\
\hline L. Cornwallis 2 & 0.004 & 0.424 & 0.97 & 0.334 & 0.38 & 1130 & 0.5 & 6.5 \\
\hline Resolute Bay median & 0.001 & 0.044 & 0.11 & 0.109 & 0.035 & 73 & 0.2 & 0.2 \\
\hline
\end{tabular}

${ }^{1}$ Conduc. $=$ specific conductance.
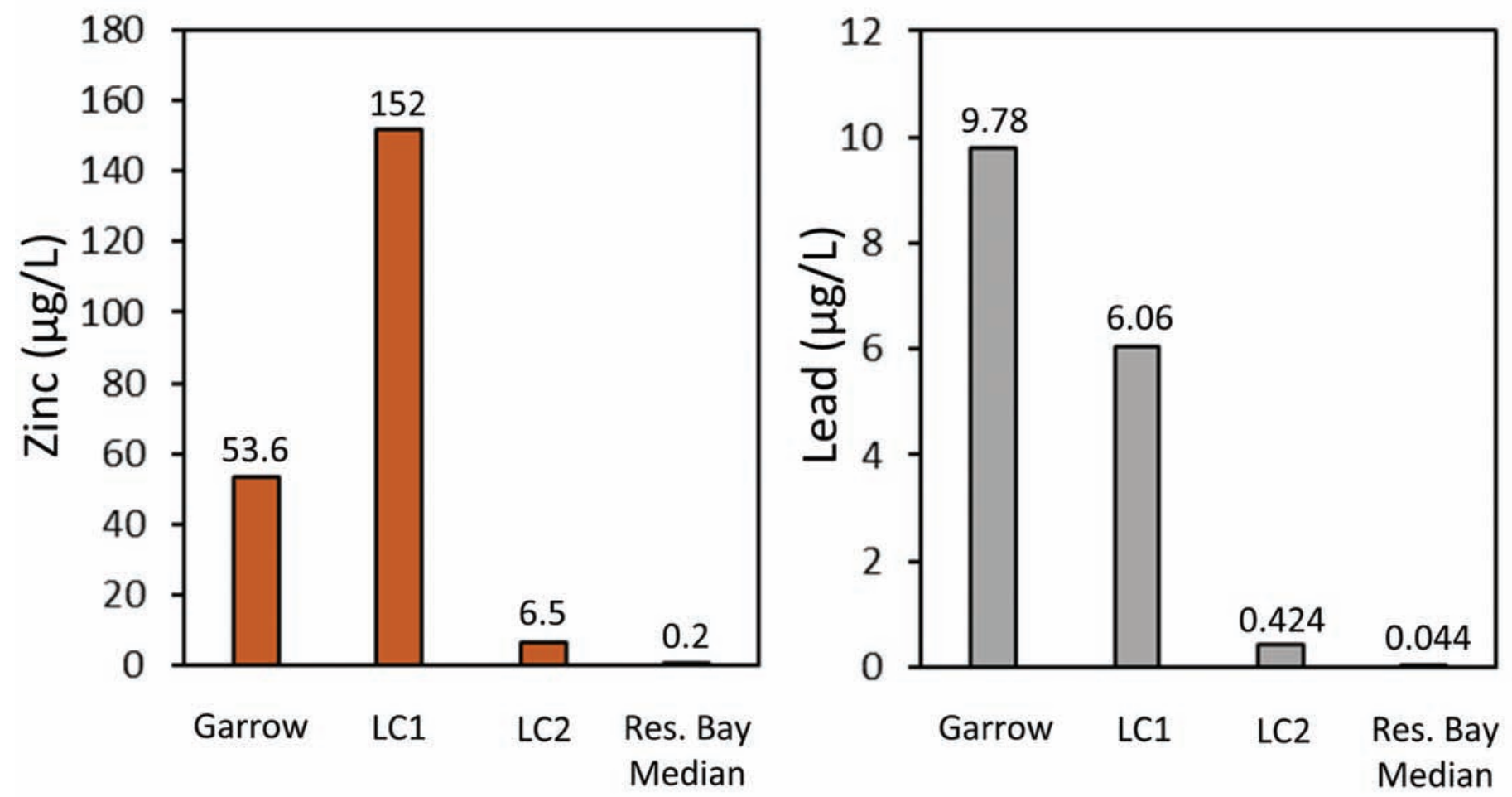

FIG. 2. Histograms showing the concentrations of zinc and lead for Garrow, Little Cornwallis 1 (LC1), and Little Cornwallis 2 (LC2) Lakes, and the median of the Resolute Bay sites for comparison. The y-axis for each element has been scaled differently.

strongly correlated with boron $(\mathrm{r}=0.92)$, cobalt $(\mathrm{r}=0.81)$, lithium ( $\mathrm{r}=0.89)$, and uranium $(\mathrm{r}=0.88)$, it was chosen to represent these variables. Similarly, manganese, aluminum, silica, and molybdenum were chosen to represent iron, gallium, fluoride, and antimony, respectively ( $\mathrm{r}$ values in Appendix 1: Table S1), and cerium was selected to represent lanthanum $(r=0.99)$ and yttrium $(r=0.96)$. Nonetheless, our reduction of water chemistry variables in the final PCA (Fig. 3) did not alter the distribution of sites and variables in the PCA ordination space as both PCAs resulted in very similar biplots (Fig. 3; Appendix 1: Fig. S1). Similarly, axes 1 and 2 explained similar amounts of variation in the water chemistry in both PCAs (Fig. 3; Appendix 1: Fig. S1).
Axis 1 of the PCA was primarily influenced by the large gradient of metal and metalloid concentrations and ionic strength of the waters, with the three Little Cornwallis sites plotted along this axis. Not surprisingly, Garrow Lake, which was the most impacted lake, plotted farthest away from all other sites along axis 1 . Specifically, the Little Cornwallis Island lakes had higher concentrations for boron, cadmium, calcium, lithium, molybdenum, sulfate, uranium, and vanadium relative to the sites near Resolute Bay (Fig. 3; Appendix 1: Table S2). Meanwhile, axis 2 of the PCA more closely tracked differences in nutrient concentrations (Fig. 3). For instance, R12 and R13 (unofficial names, from Stewart et al., 2014) plotted 


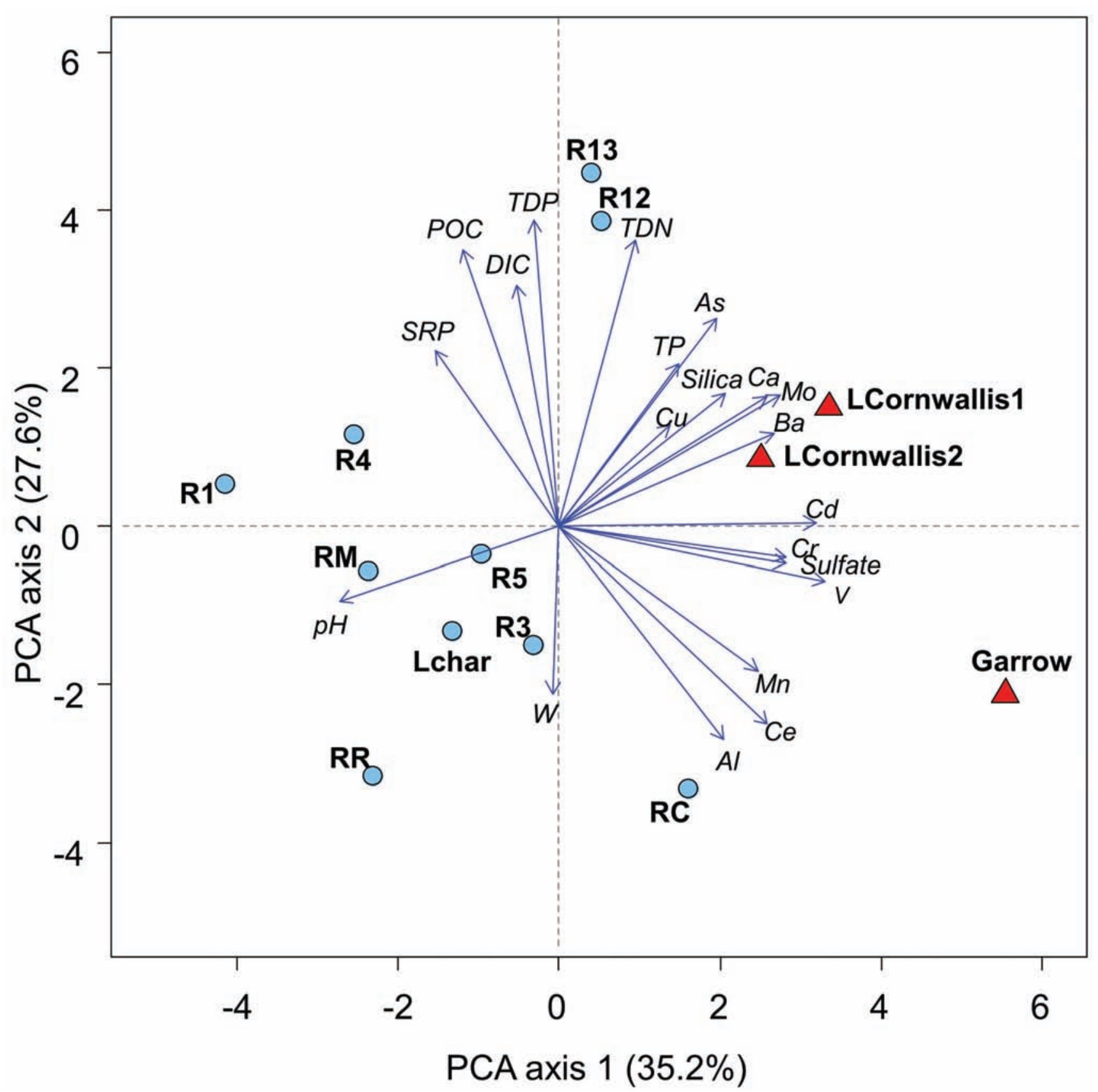

FIG. 3. A principal component analysis biplot summarizing the variability in the water chemistry parameters of 13 sites from Little Cornwallis Island (red triangles) and Cornwallis Island (blue circles). $\mathrm{RM}=$ Meretta Lake, $\mathrm{RR}=$ Resolute Lake, $\mathrm{RC}=$ Char Lake, and Lchar $=$ Little Char Lake. Further details regarding the Resolute Bay sites are provided in Michelutti et al. (2007) and Stewart et al. (2014).

separately from other Resolute Bay sites in the PCA as these ponds had relatively high concentrations of POC, TDP, TDN, TKDN, and DIC (Fig. 3; Appendix 1: Table S2). All lakes included in this survey had $\mathrm{pH}$ greater than 7 (Appendix 1: Table S2), however the lakes near Resolute Bay were slightly more alkaline (Fig. 3).

\section{DISCUSSION}

Concentrations of lead and zinc recorded in Garrow Lake $($ lead $=9.78 \mu \mathrm{g} / \mathrm{L} ;$ zinc $=53.6 \mu \mathrm{g} / \mathrm{L})$ and Little
Cornwallis $1($ lead $=6.06 \mu \mathrm{g} / \mathrm{L}$; zinc $=152 \mu \mathrm{g} / \mathrm{L})$ were some of the highest levels reported from the Canadian High Arctic Archipelago. In contrast, the study lakes and ponds near Resolute Bay had concentrations below 1 and $0.2 \mu \mathrm{g} / \mathrm{L}$ for zinc and lead, respectively (Fig. 2). Moreover, previous limnological surveys of hundreds of High Arctic freshwaters from diverse geological regions have only rarely recorded values for $\mathrm{Pb}$ and $\mathrm{Zn}$ that exceeded detection levels (Hamilton et al., 2001; Michelutti et al., 2002; Antoniades et al., 2003; Dranga et al., 2018). In fact, limnological data from Garrow Lake in the early 1980s recorded lower values for lead and zinc relative to our 2017 
data (Stewart and Platford, 1986; Ouellet et al., 1989). The present levels of zinc at Garrow Lake $(53.6 \mu \mathrm{g} / \mathrm{L})$ are lower than the levels measured after the tailings spill into the surface layer (410 $\mu \mathrm{g} / \mathrm{L}$ in 1991; Gartner Lee Ltd., 2001); nonetheless, they are an order of magnitude higher than the levels measured in other High Arctic lakes. Past mining activities appear to have left a legacy of elevated $\mathrm{Pb}$ and $\mathrm{Zn}$ concentrations in the Little Cornwallis Island study lakes.

The Canadian Water Quality Guideline (CWQG) for lead is dependent on hardness (as calcium carbonate) of the water; specifically, when hardness is above 180 $\mathrm{mg} / \mathrm{L}$ the CWQG for lead is $7 \mu \mathrm{g} / \mathrm{L}$ (CCME, 2008). Both Little Cornwallis 1 and Garrow had water hardness levels well above $180 \mathrm{mg} / \mathrm{L}(374 \mathrm{mg} / \mathrm{L}$ and $437 \mathrm{mg} / \mathrm{L}$, respectively); however, the threshold of $7 \mu \mathrm{g} / \mathrm{L}$ of lead in the water was only exceeded at Garrow $(9.78 \mu \mathrm{g} / \mathrm{L})$ while the lead concentration at Little Cornwallis $1(6.06 \mu \mathrm{g} / \mathrm{L})$ was just below the guideline. The long-term CWQG for zinc is influenced by hardness, dissolved organic carbon, and $\mathrm{pH}$ (CCME, 2018). The zinc concentration at Little Cornwallis $1(152 \mu \mathrm{g} / \mathrm{L})$ was twice as high relative to the level determined by the CWQG $(76 \mu \mathrm{g} / \mathrm{L})$. However, we could not determine if the zinc level at Garrow Lake $(53.6 \mu \mathrm{g} / \mathrm{L})$ exceeded the CWQG, as the hardness of the water was beyond the range of the equation used for the guideline (applicable over a range of $23.4 \mathrm{mg} / \mathrm{L}$ to $399 \mathrm{mg} / \mathrm{L}$ ) and the dissolved organic carbon measurements for this lake was interfered with by the exceptionally high chloride levels ( $1000 \mathrm{mg} / \mathrm{L}$; Table 1$)$.

Mine tailings are often composed of a variety of metals and metalloids even when a single metal or metalloid dominates the composition (e.g., Leppänen et al., 2017; Little et al., 2020). At the Polaris Mine, for example, the tailings were rich in zinc, yet we recorded higher levels of other heavy metals (e.g., cadmium, molybdenum, nickel, uranium, vanadium) in the Little Cornwallis Island lakes relative to the ones from Resolute Bay. The concentrations of the these heavy metals were nonetheless low, near, or below $1 \mu \mathrm{g} / \mathrm{L}$ in the Little Cornwallis Island lakes. However, they were still several times greater than those recorded on Cornwallis Island lakes and ponds with no associated mining operations (Table 1 and Appendix 1: Table S2). Specifically, the concentrations for cadmium, nickel, and vanadium were more than 30,15 , and nine times higher, respectively, at Garrow relative to median values from the Resolute Bay study sites. Furthermore, at the meromictic Garrow Lake, variables related to ionic concentrations were higher relative to other lakes in this study (Table 1), as was reported from previous limnological surveys of this lake (Stewart and Platford, 1986; Ouellet et al., 1989). Interestingly, elevated levels of salinity-related variables were also recorded at Little Cornwallis 1 . However, based on the available information, it is not possible to assert if Little Cornwallis 1 is naturally saline, or whether other factors (e.g., marine inputs or mining activities) elevated the salinity.
A growing number of investigations are identifying the long-term environmental consequences of anthropogenic activities on remote High Arctic aquatic ecosystems. For example, R12 and R13 in Resolute Bay received sewage from aboveground pipes and utilidors between 1949 and 1979 (Stewart et al., 2014). More than 30 years have passed since the cessation of sewage inputs into R12 and R13, yet these sites had some of the highest concentrations of variables related to nutrients (e.g., TP, TDP, TDN, TKDN) and production (e.g., POC) in our survey. Similarly, when we sampled the Polaris Mine study lakes in 2017, 15 years had passed since the cessation of ore extraction activities, and there were almost no visible remnants of past mining operations on the surface (e.g., waste rock, infrastructure), as has been reported in previous publications (Donald, 2005; Green, 2015). However, the elevated levels of lead and zinc in the waters of nearby lakes may suggest that past mining activities have left long-term limnological legacies.

Environmental assessments of mine-impacted freshwaters in temperate and sub-Arctic regions have provided important insights regarding the long-term geochemical cycling of industrial pollutants. Specifically, high-frequency monitoring of lakes from lower latitudes has shown that seasonality plays a critical role in remobilizing redox sensitive elements from sediments, and metal and metalloid concentrations increase in the water column during ice-covered winter months as the formation of lake ice excludes particulates (Palmer et al., 2019). Unlike the lower latitude lakes, the lakes around Polaris Mine are icecovered for the majority of the year, with an exceptionally short ice-free period, and the geochemical cycling of environmental pollutants could be different. Hence, future studies should consider examining the seasonal changes in contaminant concentrations and assessing the long-term biological impacts associated with past mining activities on Little Cornwallis Island lakes. Cumulatively, these data will assist in managing mine-impacted waters in the Arctic, which is critical given that biota in these lakes are already under stress from other global change stressors (e.g., climate change) and there may be cumulative or even synergistic effects.

\section{ACKNOWLEDGEMENTS}

We thank Bruce Donald from Teck Resources Limited for assisting us with the coordination of the site sampling on Little Cornwallis Island. Many thanks to Dave Eickmeyer, Jules Blais, Linda Kimpe, and Lauren Gallant from University of Ottawa for helping with the sampling of the Resolute Bay lakes during our 2017 field season. We are also grateful to the logistical staff of the Polar Continental Shelf Program (PCSP), Natural Resources Canada in Resolute Bay. We also thank two anonymous reviewers for providing constructive feedback on this manuscript. Financial support by the Natural Sciences and Engineering Research Council of Canada (Discovery Grant and Northern Supplements to John Smol, Alexander Graham 
Bell Canada Graduate Scholarship to Branaavan Sivarajah), Northern Scientific Training Program (Branaavan Sivarajah), Queen's University Graduate Dean's Doctoral Field Travel Grant (Branaavan Sivarajah), and PCSP (Jules Blais and John Smol) is gratefully acknowledged.

\section{REFERENCES}

Antoniades, D., Douglas, M.S.V., and Smol, J.P. 2003. Comparative physical and chemical limnology of two Canadian High Arctic regions: Alert (Ellesmere Island, NU) and Mould Bay (Prince Patrick Island, NWT). Archiv für Hydrobioligie 158(4):485-516. https://doi.org/10.1127/0003-9136/2003/0158-0485

CCME (Canadian Council of Ministers of the Environment). 2008. Canadian water quality guidelines. Ottawa, Ontario: CCME.

___ 2018. Scientific criteria document for the development of the Canadian water quality guidelines for the protection of aquatic life: Zinc. Winnipeg, Manitoba: CCME.

https://ccme.ca/en/res/zinc-en-canadian-water-qualityguidelines-for-the-protection-of-aquatic-life.pdf

Dewing, K., Sharp, R.J., and Muraro, T. 2006. Exploration history and mineral potential of the Central Arctic $\mathrm{Zn}-\mathrm{Pb}$ district, Nunavut. Arctic 59(4):415-427.

https://doi.org/10.14430/arctic290

Donald, B.J. 2005. Polaris Mine: A case study of reclamation in the High Arctic. Proceedings of the British Columbia Mine Reclamation Symposium, University of British Columbia. https://doi.org/10.14288/1.0042473

Dranga, S.A., Hayles, S., and Gajewski, K. 2018. Synthesis of limnological data from lakes and ponds across Arctic and Boreal Canada. Arctic Science 4(2):167-185.

https:/doi.org/10.1139/as-2017-0039

EC (Environment Canada). 1994a. Manual of analytical methods: Major ions and nutrients, Vol. 1. Burlington, Ontario: National Laboratory for Environmental Testing, Canadian Centre for Inland Waters.

1994b. Manual of analytical methods: Trace metals, Vol.

2. Burlington, Ontario: National Laboratory for Environmental Testing, Canadian Centre for Inland Waters.

Edlund, S.A. 1992. Vegetation of Cornwallis and adjacent islands, Northwest Territories: Relationships between vegetation and surficial materials. Geological Survey of Canada Paper 89-26. https://doi.org/10.4095/133238

Gartner Lee Ltd. 2001. Polaris Mine decommissioning and reclamation plan, Volume 1 of 4. GLL 20-935. 102-140 Refrew Drive, Markham, Ontario L3R 6B3, Canada: Gartner Lee Ltd.

Green, H. 2015. "There is no memory of it here": Closure and memory of the Polaris Mine in Resolute Bay, 1973-2012. In: Keeling, A., and Sandlos, J., eds. Mining and communities in northern Canada: History, politics, and memory. Calgary, Alberta: University of Calgary Press. 315-340.

https://doi.org/10.2307/j.ctv6gqt3h.18
Hamilton, P.B., Gajewski, K., Atkinson, D.E., and Lean, D.R.S. 2001. Physical and chemical limnology of 204 lakes from the Canadian Arctic Archipelago. Hydrobiologia 457:133-148. https://doi.org/10.1023/A:1012275316543

Houben, A.J., D’Onofrio, R., Kokelj, S.V., and Blais, J.M. 2016. Factors affecting elevated arsenic and methyl mercury concentrations in small shield lakes surrounding gold mines near the Yellowknife, NT, (Canada) region. PLoS ONE 11(4): e0150960.

https://doi.org/10.1371/journal.pone.0150960

Keatley, B.E., Douglas, M.S.V., and Smol, J.P. 2007. Limnological characteristics of a High Arctic oasis and comparisons across northern Ellesmere Island. Arctic 60(3):294-308. https://doi.org/10.14430/arctic221

Keeling, A., and Sandlos, J., eds. 2015. Mining and communities in northern Canada: History, politics, and memory. Calgary, Alberta: University of Calgary Press. https://doi.org/10.2307/j.ctv6gqt3h

Leppänen, J.J., Weckström, J., and Korhola, A. 2017. Multiple mining impacts induce widespread changes in ecosystem dynamics in a boreal lake. Scientific Reports 7: 10581. https://doi.org/10.1038/s41598-017-11421-8

Lim, D.S.S., Douglas, M.S.V., Smol, J.P., and Lean, D.R.S. 2001. Physical and chemical limnological characteristics of 38 lakes and ponds on Bathurst Island, Nunavut, Canadian High Arctic. International Review of Hydrobiology 86(1):1-22. https://doi.org/10.1002/1522-2632(200101)86:1<1::AIDIROH1>3.0.CO;2-E

Little, A.J., Sivarajah, B., Frendo, C., Sprague, D.D., Smol, J.P., and Vermaire, J.C. 2020. The impacts of century-old, arsenicrich mine tailings on multi-trophic level biological assemblages in lakes from Cobalt (Ontario, Canada). Science of the Total Environment 709: 136212. https://doi.org/10.1016/j.scitotenv.2019.136212

Markager, S., Vincent, W.F., and Tang, E.P.Y. 1999. Carbon fixation by phytoplankton in High Arctic lakes: Implications of low temperature for photosynthesis. Limnology and Oceanography 44(3):597-607.

https://doi.org/10.4319/1o.1999.44.3.0597

Michelutti, N., Douglas, M.S.V., Lean, D.R.S., and Smol, J.P. 2002. Physical and chemical limnology of 34 ultra-oligotrophic lakes and ponds near Wynniatt Bay, Victoria Island, Arctic Canada. Hydrobiologia 482:1 - 13 . https://doi.org/10.1023/A:1021201704844

Michelutti, N., Douglas, M.S.V., and Smol, J.P. 2007. Evaluating diatom community composition in the absence of marked limnological gradients in the High Arctic: A surface sediment calibration set from Cornwallis Island (Nunavut, Canada). Polar Biology 30:1459-1473. https://doi.org/10.1007/s00300-007-0307-x

Michelutti, N., Tapia, P.M., Labaj, A.L., Grooms, C., Wang, X., and Smol, J.P. 2019. A limnological assessment of the diverse waterscape in the Cordillera Vilcanota, Peruvian Andes. Inland Waters 9(3):395-407.

https://doi.org/10.1080/20442041.2019.1582959 
Nassichuk, W.W. 1987. Forty years of northern non-renewable natural resource development. Arctic 40(4):274-284. https://doi.org/10.14430/arctic1784

Ouellet, M., Dickman, M., Bisson, M., and Pagé, P. 1989. Physicochemical characteristics and origin of hypersaline meromictic Lake Garrow in the Canadian High Arctic. Hydrobiologia 172:215-234. https://doi.org/10.1007/BF00031624

Palmer, M.J., Chételat, J., Richardson, M., Jamieson, H.E., and Galloway, J.M. 2019. Seasonal variation of arsenic and antimony in surface waters of small subarctic lakes impacted by legacy mining pollution near Yellowknife, NT, Canada. Science of the Total Environment 684:326-339. https://doi.org/10.1016/j.scitotenv.2019.05.258

R Core Team. 2019. R: A language and environment for statistical computing. Vienna, Austria: R Foundation for Statistical Computing. https://www.r-project.org/

Silke, R. 2009. The operational history of mines in the Northwest Territories, Canada: An historical research project. https://buyandsell.gc.ca/cds/public/2014/05/27/edcb878b7f96 eld30e5359a53406c671/ABES.PROD.PW_NCS.B107.E10183. ATTA040.PDF
Sivarajah, B., Korosi, J.B., Blais, J.M., and Smol, J.P. 2019. Multiple environmental variables influence diatom assemblages across an arsenic gradient in 33 subarctic lakes near abandoned gold mines. Hydrobiologia 841:133-151. https://doi.org/10.1007/s10750-019-04014-1

Stewart, E.M., McIver, R., Michelutti, N., Douglas, M.S.V., and Smol, J.P. 2014. Assessing the efficacy of chironomid and diatom assemblages in tracking eutrophication in High Arctic sewage ponds. Hydrobiologia 721(1):251-268. https://doi.org/10.1007/s10750-013-1667-6

Stewart, K.M., and Platford, R.F. 1986. Hypersaline gradients in two Canadian High Arctic lakes. Canadian Journal of Fisheries and Aquatic Sciences 43(9):1795-1803. https://doi.org/10.1139/f86-223

Thorsteinsson, R. 1958. Cornwallis and Little Cornwallis Islands, District of Franklin Northwest Territories. Memoir 294. Ottawa, Ontario: Geological Survey of Canada.

https://doi.org/10.4095/100516 